\title{
A CRITICAL ANALYSIS OF SANAVIYAH AMAH CURRICULUM OF MADRASAH IN PAKISTAN
}

\author{
Hameedullah Bhutto* \\ Dr. Ibrahem Narongraksakhet ${ }^{* *}$ \\ DOI: 10.29370/siarj/issue4ar10 \\ Link: https://doi.org/10.29370/siarj/issue4ar10
}

\begin{abstract}
:
The credibility of research in history depends on the credibility of sources referred to in the process and the way they are interpreted. Accordingly, it is imperative, firstly, to select the right sources, and secondly, to thoroughly analyze and question them. The situation, in many instances, gets aggravated when researchers find contradicting information from various sources. Such a situation necessitates paying due attention to the contexts in which these works were written, the potential influences that the authors may have faced, and the way in which such works were transmitted. This paper is an attempt make a contribution in this direction in relation to a few key primary and secondary sources of Mongol history that can extremely vital in reconstructing their times, their mindset, their empire and the horrific invasions they are known for. We have presented a brief overview of 15 important classical historical sources that shed light on the Mongol history and their conquests. Though most of the major events appear to be mentioned in these works, however, while reviewing these works, difference can be noticed in terms of author's opinions and support (or lack thereof) for those events and underlying decisions from various players appearing in the picture. We also see a tint of political influence in these works. Some of the works are known to have mistakes

\footnotetext{
${ }^{*}$ Ph.D Candidate, College of Islamic Studies, Prince of Songkla University, Pattani Campus, Thailand. Email: hameedullah.bhutto@usindh.edu.pk

** Associate Professor, College of Islamic Studies, Prince of Songkla University, Pattani Campus, Thailand.Email:

nibrahem@bunga.pn.psu.ac.th
} 
in terms of certain specific information about the events and persons involved. Historical sources selected for this study were either written as the relevant events were unfolding, or written within a few centuries after the events took place. In these sources, we also notice that some of the authors were the direct eyewitnesses of the incidents whereas others relied on second or third-hand information. Accordingly, it becomes important for researchers to understand these factors in order to correctly reference from these works and contribute to the body of knowledge on the subject in a meaningful and healthy way.

KEYWORDS: Madrasah, Curriculum, Tyler's theory, Integrated Curriculum and Pakistan

\section{Introduction:}

Pakistan has three types of educational systems: government, private and Madrasah (Shirazi, 2015:6-7). Government and private are known as mainstream education system, while Madrasah is known as parallel education system of religious studies to the main stream education in Pakistan. Madrasah education system provides free Islamic education. The basic purpose of Madrasah education system is to maintain and intact the establishment of Mosque and Madrasah in the Muslim society that produces human resource in terms of religious education and services (AlRashdi, 2007:175). This education system came into being after 1857 in the south Asia with the advent of British rule (Khalid Rahman, 2009:57, Al-Rashdi, 2007:223). The British divided the system of education into two domains, i.e. Madrasah and the secular schools; the framework and objectives of the curricula were very different of both systems (Khalid Rahman, 2009:57). In 1947, Pakistan became independent country through the partition of India. At that time both systems were not sufficient to be implemented as an individual education system of the country (Usmani, 2000: 44). Pakistan, being an ideological state, was in need for such 
education system that should be balanced and effective in the requirements of material and spiritual needs (Siddiqui, 1991: 3). Unfortunately government could not initiate such steps in shaping any educational system that might fulfil both requirements. Consequently, both educational systems go together simultaneously till to date.

Madrasahs have their own management system under five wafaqs (federations) in Pakistan, namely (i) Wafaq-ul-Madaris Al-Salafia, (ii) Wafaq-ul-Madaris Al-Arabiah, (iii) Tanzim-ul-Madaris Ahl Sunnat, (iv) Wafaq-ul-Madaris Al- Shiah and (v) Rabitat-ul-Madaris Al-Islamiah (Nordic, 2006:26). These wafaqs are identified with a particular school of thought (Ahl-e-Hadith, Deobandi, Barelwi, Shia and Jamat Islami respectively); they affiliate their concerned Madrasahs, develop curricula, establish standards, conduct examinations and issues certificates of various levels (Ahmed Mumtaz, 2009:3).

\section{Madrasah Curriculum}

The origin of Madrasah curriculum can be traced backed to late seventeenth century when Mulla Nizamuddin Sehalvi set up a Madrasah at the Firangi Mahal, Lucknow, India. Its standardized curricula were named as Dars Nizami after his death in 1748 (Malik, 2008). It included "revealed sciences" (wahhi) and "rational sciences" (ma'qulat). The revealed sciences included study of the Quran, Hadith, Quranic commentary, and Islamic jurisprudence. The rational sciences included Arabic language/grammar to help understand the Quran, Persian language / grammar, logic, rhetoric, and philosophy that would befit prospective bureaucrats / judges (Haqqani, 2002). Even three centuries later, Dars Nizami still continues to be the standard course of most of the Madrasahs 
in Pakistan (Malik, 2008). The duration of the course is generally eight years.

\section{Implementation of Tyler's theory for analyzing curriculum of} Sanaviyah Amah of wafaqs:

Tyler's curriculum theory is applied in this study to analyze curriculum of Sanaviyah Amahof all wafaqs. His theory mainly focusing on four aspects: (i) Educational philosophy, aims, goals and objectives, (ii) Curriculum contents which act as a means of attaining these goals and objectives, (iii) Method of teaching which provides the organization of learning experiences, and (iv) Evaluation for determining learning outcomes.

\section{Philosophy, aims, goals and objectives of Madrasah education:}

Philosophy for any educational program is indispensable as it delivers a general framework for curriculum development to attain educational objectives. Tyler (2013:34) proposes use of educational philosophy as a screen for selecting and eliminating educational objectives. But the documents of wafaqs' curriculum don't provide clear information about any educational philosophy that illustrates the aims, goals and objectives of Madrasah education. Only Rabitat-ul-Madaris AlIslamiah (2010:5-6) and Wafaq-ul-Madaris Al-Salafia (2011:4) have mentioned some aims and objectives of their wafaqs those likely seem mission statements rather than educational objectives. How is it possible that Madrasah education system is effectively operational without any educational philosophy? It means this system has some hidden philosophies that make it survive in the society. The review of literature 
reveals two factors to answer this question; those are mentioned earlier in the introduction. First, this education system was started in 1857as a movement to maintain and intact the establishment of Mosque and Madrasah in the Muslim society; then this movement became the philosophy or philosophy cum movement to continue this education system. Second, this education system is dire need of the society as it provides free religious education and social services. This basic need of society, in terms of religious education and services, makes this system alive and effective.

\section{Curriculum contents of all Wafaqs "Federations":}

Curriculum content is the raw material for the students by which they are expected to meet the purpose of the education established for the curriculum (Sowel1996:154) According to Taba (1962:267-285) curriculum contents should be valid and significant, learnable and adaptable to students' experiences, consistent with social and cultural realities, balance of breadth and depth, provide for a wide range of objectives and appropriate to the needs and interests of the students. To select the curriculum contents and text books all wafaqs have special committees comprises on subject specialists and well experienced and learned scholars.

In the past, due to the pressure of government and civil society some secular and modern subjects were integrated up to Sanaviyah Amahs in the curriculum of all wafaqs to modernize and integrate the Madrasah education system with mainstream. The researchers analyzed the Sanaviyah Amah curriculum contents of all wafaqs comparatively to find out the similarities and resemblances among their curricula and uniformity with each other. For that purpose, researchers deeply studied the curricula of all wafaqs. The results of that comparative analysis study are discussed 
one by one under the description of the subjects. The highest number of subjects 15 and the lowest number 12 are recorded in all five wafaqs (see figure 1) in Sanaviyah Amah curriculum. Following subjects are implemented in five wafaqs:

1. Religious Subjects: Holy Qur'an; Tajwid (Elocution); Hadith (Apostolic Tradition); Fiqh (Jurisprudence); Aqaid (Scholasticism); Sirat (Biography of the Prophet); Ethics; Mantiq (Logic); Islamic Studies; Usul Fiqh (Principles of Jurisprudence).

2. Languages: Arabic Language; Arabic (Translation and conversation); Sarf (Etymology); Nahv (Syntax); Maani wa Bayan (Rhetoric); English; Urdu.

3. Main Stream (Integrated) Subjects: Science; Mathematics; Computer; Pakistan Studies.

Comparative Study of curriculum contents of all wafas under the description of subjects:

1. The Holy Qur'an: The translation of the Holy Qur'an is the core subject of all wafaqs in both years of Sanaviyah Amah. Very special attention is being paid to teach the translation of the Holy Qur'an. Tanzimul-Madaris Ahl Sunnat Pakistan, Wafaq-ul-Madaris Al- Shiah and Rabitatul-Madaris Al-Islamiah are common in the selection of chapters (from chapter one to chapter nine) for the translation of the Holy Qur'an with minor differences; albeit Wafaq-ul-Madaris Al-Salafia went bit ahead and selected chapters from ten to eighteen chapters. Wafaq-ul-Madaris AlArabiah is totally different from other wafaqs as it selected chapters from seventy eight to one hundred and fourteen chapters. However, this portion of chapters; is the part of middle level before Sanaviyah Amah of other 
wafaqs. 2. Tajwid: Tajwid is the science of elocution that enables students to recite the Holy Qur'an with proper accent and beautiful voice. Tajwid is employed in the curricula of all wafaqs except Wafaq-ul-Madaris AlShiah. Text books of Tajwid are diffrenet. Only two books "Jamal AlQur'an" and "Fawaid Makkiah" are common between Wafaq-ul-Madaris Al-Arabiah and Rabitat-ul-Madaris Al-Islamiah. Almost all wafaqs selected last part of the Holy Qur'an but some differences in the practice of Tajwid with memorizing the verses of the Holy Qur'an.

3. Hadith: Hadith subject is included in curriculum of all wafaqs except Tanzim-ul-Madaris Ahl Sunnat Pakistan. This subject is included in both years of Sanaviyah Amah. Text books of Hadith are diffrenet. Only one book Zad Al-Talibin is common between Wafaq-ul-Madaris AlArabiah and Rabitat-ul-Madaris Al-Islamiah. And, Wafaq-ul-Madaris AlSalafia has an additional book of subject Usul Hadith "Risalah Usul Hadith by Muhammad Awais Bilgirami Nadvi" in the second year. 4. Fiqh: Fiqh subject is the part of all wafaqs except Wafaq-ul-Madaris AlSalafia. This subject is included in both years of Sanaviyah Amah of all wafaqs except Wafaq-ul-Madaris Al-Arabiah, it added this subject in one year only. Texts books of Fiqh are different in each wafaq; only Wafaq-ulMadaris Al-Arabiah and Rabitat-ul-Madaris Al-Islamiah have same book "Quduri” but differ in teaching method; the book is entitled for one year in the curriculum of Wafaq-ul-Madaris Al-Arabiah, while it is divided in two portions for two years in the curriculum of Rabitat-ul-Madaris AlIslamiah.

5. Aqaid: Aqaid subject is part of only three wafaqs, namely Wafaq-ul-Madaris Al-Salafia, Tanzim-ul-Madaris Ahl Sunnat and Wafaqul-Madaris Al- Shiah with different text books. Wafaq-ul-Madaris AlSalafia and Tanzim-ul-Madaris Ahl Sunnat allocated this subject for one 

year, while Wafaq-ul-Madaris Al- Shiah allocated it for two years. 6. Sirat: Sirat subject is incorporated in only curriculum of Wafaq-ulMadaris Al-Salafia and Rabitat-ul-Madaris Al-Islamiah but they are different in text books and years. 7. Ethics: Ethics subject is employed in the curriculum only by Wafaq-ul-Madaris Al- Shiah for both years in Sanaviyah Amah.

8. Mantiq: All wafaqs encompassed Mantiq subject in their curricula except Wafaq-ul-Madaris Al-Salafia. Mantiq is included in the curriculum of Wafaq-ul-Madaris Al- Shiah for two years, while rest of wafaqs included it for one year in their curriculum. The text books are different in each wafaq; only Wafaq-ul-Madaris Al-Arabiah and Rabitatul-Madaris Al-Islamiah are common to "Taisir Al-Mantiq" and "Mirqat". 9. Islamic Studies: In the main stream curriculum, Islamic studies, is a compulsory subject to impart the religious education among the students of main stream education system. Wafaq-ul-Madaris Al-Arabiah is the only one wthat integrated this subject from main stream curriculum. 10. Usul al-Fiqh: Usul Fiqh subject is added in curriculum of Sanaviyah Amah only by Wafaq-ul-Madaris Al- Shiah for one year. 11. Arabic: Arabic subject is an integral part of curricula of all wafaqs and contained in both years of Sanaviyah Amah. Each wafaq is different from each other in terms of text books; although Tanzim-ul-Madaris Ahl Sunnat and Rabitat-ul-Madaris Al-Islamiah are common in text book "Tariqah Jadidah".

12. Sarf: Sarf subject is included in curricula of all wafaq except Wafaq-ul-Madaris Al- Shiah. Sarf is included in both years of Sanaviyah Amah. There is variety of text books but "Ilm Al- Sarf (Akhirain)", "Mizan Al-Sarf", "Manshiab", "Ilm Al-Sighah" and "Fusul Akbari” are the most common text books among them. 13. Nahv: Nahv subject is the 
part of all wafaqs' curricula and included in both years of Sanaviyah Amah. With different varieties of text books "Ilm Al-Nahv", "Sharh Miata Amil", "Hidayat Al-Nahv" and "Nahv Mir" are most common among them. 14. Maani wa Bayan: Maani wa Bayan subject is part of curricula of all wafaqs except Tanzim-ul-Madaris Ahl Sunnat. Maani wa Bayan subject is included in the curriculum of all wafaqs for one year. The text books are different; only Wafaq-ul-Madaris Al-Arabiah and Rabitat-ulMadaris Al-Islamiah are common in text book "Mualim Al-Insha".

15. English: Due to the importance of English language in the modern age, this subject is integrated from the curriculum of main stream education system. Wafaq-ul-Madaris Al-Arabiah and Tanzim-ul-Madaris Ahl Sunnat have included this subject for one year, while Wafaq-ulMadaris Al-Salafia and Rabitat-ul-Madaris Al-Islamiah included it for two years in their curriculum. English subject is not included in the curriculum of Wafaq-ul-Madaris Al- Shiah. As far as the text books are concerned every wafaq has adopted different text book. For example Wafaq-ulMadaris Al-Salafia refers to Punjab Text Book Board, Wafaq-ul-Madaris Al-Arabiah mentions as "suggested by the government", Tanzim-ulMadaris Ahl Sunnat has printed its own text book according to the main stream curriculum and Rabitat-ul-Madaris Al-Islamiah suggests concerned (provincial) Text Book Board. 16. Urdu: Urdu is a national language of Pakistan and is the part of main stream curriculum as a compulsory subject of Sanaviyah Amah. Only Wafaq-ul-Madaris Al-Arabiah and Rabitat-ulMadaris Al-Islamiah have integrated Urdu subject in their curricula; Wafaq-ul-Madaris Al-Arabiah included it for one year while, Rabitat-ulMadaris Al-Islamiah for two years.

17. Science: Science subject is also integrated from the main stream curriculum to impart the basic knowledge of science among the 
students of Madrasah. Only Wafaq-ul-Madaris Al-Salafia, Wafaq-ulMadaris Al-Arabiah and Tanzim-ul-Madaris Ahl Sunnat have added this subject in their curriculum. Wafaq-ul-Madaris Al-Salafia has included it for two years and suggested Punjab Text Book Board. Wafaq-ul-Madaris Al-Arabiah included it for one year and suggested text book according to the government policy. Tanzim-ul-Madaris Ahl Sunnat has printed its own text book according to the main stream curriculum and included this subject for one year. 18. Mathematics: Mathematics subject is integrated from the curriculum of main stream education system. Wafaq-ul-Madaris Al-Salafia and Rabitat-ul-Madaris Al-Islamiah have added this subject for two years, while Wafaq-ul-Madaris Al-Arabiah and Tanzim-ul-Madaris Ahl Sunnat included it for one year in their curriculum. Mathematics is not included in the curriculum of Wafaq-ul-Madaris Al- Shiah. As far as the text books are concerned every wafaq has adopted different text books. For example Wafaq-ul-Madaris Al-Salafia refers to Punjab Text Book Board; Wafaq-ul-Madaris Al-Arabiah mentions as "suggested by the government". Tanzim-ul-Madaris Ahl Sunnat has printed its own text book according to the main stream curriculum, and Rabitat-ul-Madaris AlIslamiah suggests concerned (provincial) Text Book Board. 19. Computer: Only Wafaq-ul-Madaris Al-Salafia integrated Computer subject as an optional subject and included it for both years of Sanaviyah Amah. Text book of computer is referred to Punjab Text Book Board.

20. Pakistan Study: As Pakistan is an ideological state, Pakistan study is the compulsory subject of main stream curriculum to make the students more ideological nation. To follow the government's educational policy, all wafaqs incorporated Pakistan study subject in their curricula except Wafaq-ul-Madaris Al- Shiah. All wafaqs included this subject for one year except Rabitat-ul-Madaris Al-Islamiah that included it for two 
years. For the text book of Pakistan study, Wafaq-ul-Madaris Al-Salafia refers to Punjab Text Book Board, Wafaq-ul-Madaris Al-Arabiah mentions as "suggested by the government"; Tanzim-ul-Madaris Ahl Sunnat has printed its own text book according to the main stream curriculum, and Rabitat-ul-Madaris Al-Islamiah suggests concerned (provincial) Text Book Board. 
Figure 1: Shows Analytical Assessment of the Subjects in

\section{Concerned Wafaq.}

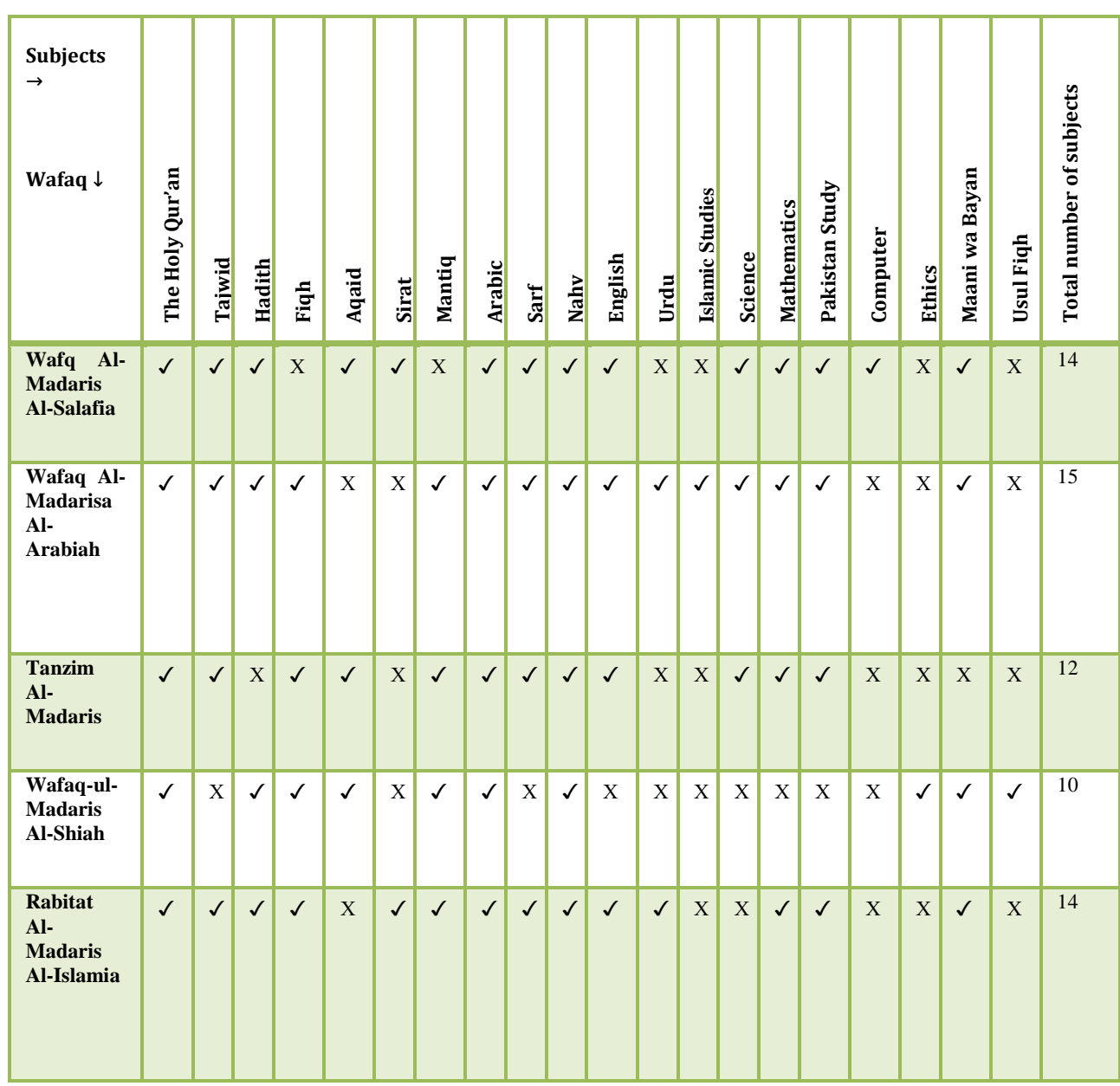

After the comparative study of curricula of all wafaqs, it shows that they are almost common in terms of selecting subjects with some differences in their curricula, but they are not common in the selection of text books, and the structure of the curriculum is also different from each other. Wafaq-ulMadaris Al-Arabiah is unique and individual for making Sanaviyah Amah in three years. Because of the demand of government and stakeholders, all wafaqs integrated some subjects from main stream into their curricula except Wafaq-ul-Madaris Al- Shiah. Text books are not unified. Every wafaq suggests different text books; only Tanzim-ul-Madaris prepared its own text books according to the government policy. Rabitat-ul-Madaris Al-Islamiah has included "Pakistan" and "Urdu" subjects in its curriculum 
for two years, unlike in main stream's curriculum. Therefore, there is no classification of compulsory or optional subjects in the curricula of all wafaqs except Wafaq-ul-Madaris Al-Salafia that has maintained religious subjects as compulsory and integrated subjects of main stream as optional subjects. Rabitat-ul-Madaris Al-Islamiah suggests some extra books to the students apart from the curriculum to develop the habit of self-study.

\section{Method of teaching:}

Teaching students or imparting knowledge to the learners actually is organizing of curriculum contest in the best way. The success of any curriculum depends on effective teaching methodology to attain the objectives. As Taba (1962:290) stated sometimes curriculum is ineffective not because its curriculum is inadequate but because it is put together in a way that makes learning difficult or less effective and less productive.

The teaching methodology in Madrasahs is old and traditional. Khalid (2008:39) shares his observations that teaching methodology in Madrasahs is still in a traditional way except some Jamia'at (Madrasahs who provides graduation level education). Here traditional way means teacher reads the content of text book and explains the textual meaning to the students where hardly ten percent of students participate in this method who listen the teacher (Nadvi. n.d: 88). The whole curriculum of Madrasahs is confined to book oriented only. Objectives and teaching methodology are not mentioned anywhere in the curriculum (Khalid S.M. 2004:266). Also, there is no formal or informal system available for teachers' training in Madrasahs for effective teaching (Khalid S.M. 2004:337).

Due to the ineffective teaching and passive method of imparting knowledge, students cannot participate in active learning process. This affects students' abilities and their critical and creative thinking, but it also leads towards narrow-mindedness. 


\section{Evaluation:}

Evaluation plays a significant role in the curriculum development. It not only identifies the strengths and weaknesses of the curriculum, but it also helps to find out the desired goals and results of proposed curriculum. According to the Tyler (2013:105-106) evaluation is the process of determining to what extent the educational objectives are being realized by the curriculum. Saylor et. al. (1981:316) describe evaluation as a process used in judging the appropriateness of curriculum choices. However, evaluation is defined in various ways with association of various aspects in the subject of curriculum. Following the Tyler's theory, evolution must appraise the behavior of the students, and it also must be more than one time to check the behavioral changes in the students (Tyler 2013: 106). This evaluation can be conducted at the beginning and at the end of any educational program to measure the behavioral changes in the students. Evaluation process can be assessed by paper and pencil devices, questionnaires, interviews, observations, and records.

Before the establishment of wafaqs, there was no any formal system for evaluation process in Madrasah education. The scholars' written permission was provided to the pupils allowing them to teach anywhere and any person. The permission was based on the scholars' observation and considered as a certificate and degree that was accepted in the society. After establishment of wafaqs, the modern evaluation was implemented through examination system. Parcha (1993:160) expressed his views that since Madrasahs have initiated central examination system that resulted remarkable increase in the standard of Madrasah education. Moreover, the evaluation system of wafaqs is confined to students' 
assessment through paper and pencil devices, observations, and interviews. All wafaqs conduct the Sanaviyah Amah examination of their affiliated Madrasahs once at the end of second year.

\section{Major Findings:}

\section{Strengths of the Curriculum of Sanaviyah Amah:}

- Curriculum contents are valid and significant.

- Curriculum contents are learnable and adaptable to students' experiences.

- Curriculum contents are balance of breadth and depth.

- Curriculum contents can provide for a wide range of objectives.

- Curriculum contents are consistent with social and cultural realities.

- Curriculum contents are appropriate to the needs and interests of the students.

- Curriculum contents and text books selected through committees comprises on subject specialists and well experienced scholars.

- Curriculum contents are integrated with some secular and modern subjects were to modernize and integrate the Madrasah education system with mainstream.

- Students become able to translate the verses of Holy Quran in their mother tongue and explain in own words.

- Students become able to recite the Holy Quran with proper accent and beautiful voice.

- Students' memory becomes stronger by memorizing some chapters from the Holy Quran and Hadith. 
- Students become able to translate Hadith in their mother tongue and explain in own words.

- Students learn two foreign languages, i.e. Arabic and English.

- Students get their education free of cost.

- Students get sound knowledge about religion and faith.

- The evaluation of students' behavior is assessed through paper and pencil devices, observations, and interviews (oral examination).

\section{Weaknesses of the Curriculum of Sanaviyah Amah:}

- There is no clear educational philosophy for Madrasah education.

- Aims, goals and objectives of Sanaviyah Amah Madrasah education are not formulated and set.

- Some curriculum contents of Figh subjects are not valid and outdated.

- Lack of curriculum contents of modern Fiqh in Fiqh subject.

- Curriculum contents of Mantiq subject are not learnable and adaptable to students' experiences at Sanaviyah Amah.

- Curriculum contents of Maani wa Bayan subject are not learnable and adaptable to students' experiences at Sanaviyah Amah.

- Curriculum contents of Usul Fiqh subject are not learnable and adaptable to students' experiences at Sanaviyah Amah.

- Unnecessary consideration towards Sarf and Nahv subject is paid at large scale.

- The teaching methodology is old and traditional.

- Ineffective teaching and passive method of imparting knowledge.

- Students cannot participate in active learning process due to poor teaching methodology. 
- Traditional teaching methodology affects students' abilities and their critical and creative thinking.

\section{Conclusions}

In conclusion, literature review and analysis reveal that there is no clear educational philosophy found in the curriculum of wafaqs that can select and eliminate goals and objectives of Madrasah education. The curriculums of all wafaqs need an educational philosophy to select the educational goals, objectives and standards.

Curriculum contents are valid, learnable and consistent with needs of society and students. Curriculum contents are integrated with modern subjects to modernize and integrate the Madrasah education system with mainstream. Moreover, adequate guidelines and teacher training are not ensured in the curriculum; consequently, teachers are not able to refine the curriculum according to their particular needs and needs of their students.

Furthermore, the evaluation system of wafaqs is confined to students' assessment only through examination system, but evaluation system to identify weaknesses of existing curriculum; teachers' delivery and policy formulation do not functionally exist at any wafaq. Finally, study suggests that all wafas should prepare a specific educational program with a well-structured curriculum that describes the clear educational philosophy, goals, objectives, learning experiences and evaluation. The educational program of all wafaqs should be valid educationally and accepted by teachers, students, parents and the society. 


\section{REFERENCES}

Ahmed Mumtaz, (2009). Madrasa Reforms and Perspectives: Islamic Tertiary and Education in Pakistan. The National Bureau of Asian Research. Retrieved September 27, 2016 from file:///C:/Users/IamMuslim/Downloads/1.pdf Al-Rashdi, Abu Ammar Zahid, (2007). “Islam Ka Tasawur Ilm aur Dini Madaris Ka Kirdar" in Dini Madaris aur Asr Hazir. Shabir Ahmed Khan Miwati (ed.). Al-Shariah Academy, Lahore, Pakistan.

Haqqani H (2002, December 2). 'Islam's Medieval Outposts', Foreign Affairs Policy, Carnegie.

Khalid, Rehman (2008) Dini Madaris: Tabdili Kay Rujhanat. Institute of Policy Studies. Islamabad. Pakistan.

Khalid Rahman, (2009). “Madrasahs in Pakistan: Role and Emerging Trends” in

Islam and Politics. Amit Pamdya and Ellen Laipson (eds.) The Henry L. Stimson Centre, Washington, DC.

Khalid S.M. (2004). Dini Madaris maen Ta'alim. Institute of Policy Studies. Islamabad. Pakistan.

Malik J (2008). Madrasah in South Asia: teaching terror? Abingdon, United Kingdom: Routledge, Taylor and Francis Group.

Nadvi, Abu al-Irfan (n.d). Dini Madaris aur Jadid Tariqah Tadris. Lucknow. India.

Nordic Recognition Information Centres, (2006). Report on The System of Education in

Pakistan. Retrieved September 27, 2016 from http://norric.org/files/education-systems/Pakistan-2006.pdf

Paracha, Farid Ahmed (1993). “Dini Madaris Maen Amali Islahi Iqdamat” in Dini Madaris ka nizam Ta'alim. Khalid, S.M. and Muslim Sajad (eds.). Institute of Policy Studies. Islamabad. Pakistan.

Rabitat-ul-Madaris-Al-Islamiah, Pakistan, (2010). Dastur aur Nisab Talim. Lahore, Pakistan.

Saylor, J.G., Alexander, W.M. \& Lewis, A.J (1981). Curriculum planning for better teaching and learning. Japan: Holt, Rinchart and Winston.

Shirazi, Syed Ma'aroof Shah, (2015). Yaksan Nizam Ta'alim, Nursery ta Dars Nizami University. Zilal Al-Qur'an Foundation, Islamabad, Pakistan. 
The Scholar (January- June 2017)

A Critical Analysis of Sanaviyah Amah ......1-19

Siddiqui, Mushtaq Al-Rehman, (1991). “Ta'alim aur Qomi Taqazey” in Qomi Ta'alim aur Oskey Taqazey. Mushtaq Al-Rehman Siddiqui and Muhammad Husain Malik (eds). Tanzim Asatizah, Lahore, Pakistan.

Sowel, Evelyn J. (1996) Curriculum: An Integrative Introduction. Prentice-Hall,Inc. Englewood Cliffs, New Jersey.

Taba, H (1962). Curriculum development theory and practice.USA.: Harcourt Brace Jovanovich Inc..

Tanzim-ul-Madaris Ahl Sunnat, Pakistan, (2013). Nisab Talim (for boys). Retrieved July 16, 2016 from http://tanzeemulmadaris.com/Syllabus.aspx?Path Id=5

Tyler, R.W (2013). Basic principles of curriculum and instruction. The University of Chicago Press. Chicago.

Usmani, Muhammad Rafi, (2000). Musalmanun KI Ta'alimi Policy Tarikh Kay A'inay Maen. Bait Al-Uloom, Lahore, Pakistan.

Wafaq-ul-Madaris Al- Shiah, (n.d). Tadrisi Nisab. Retrieved August 21, 2016 from http://jamiatulmuntazar.com/\#

Wafaq-ul-Madaris Al-Salafia, (2011). Nisab Talim aur Nizam Imtihanat. Faisalabad, Pakistan.

Wafaq-ul-Madaris-Al-Arabiah Pakistan, (2015). Nisab Talim. Multan, Pakistan. 